\title{
Gigantol attenuates the proliferation of human liver cancer HepG2 cells through the PI3K/Akt/NF-кB signaling pathway
}

\author{
HUANHUAN CHEN $^{1 *}$, YUECHUN HUANG $^{2 *}, \mathrm{JUNBIN} \mathrm{HUANG}^{1}$, LIZHEN LIN $^{1}$ and GANG WEI ${ }^{1}$ \\ ${ }^{1}$ School of Chinese Pharmaceutical Science, Guangzhou University of Chinese Medicine, Guangzhou 510006; \\ ${ }^{2}$ The First Affiliated Hospital, Guangzhou University of Chinese Medicine, Guangzhou 510405, P.R. China
}

Received June 20, 2016; Accepted July 28, 2016

DOI: 10.3892/or.2016.5299

\begin{abstract}
Gigantol is a phenolic substance extracted from plants in the genus Dendrobium and used in traditional Chinese medicine. In the present study, we aimed to investigate the growth inhibition and apoptotic effects of gigantol on human liver cancer cells through the PI3K/Akt/NF- $\mathrm{BB}$ signaling pathway. HepG2 cells were treated with different concentrations of gigantol $(0-150 \mu \mathrm{M})$ for 12,24 and $48 \mathrm{~h}$. It was found that gigantol significantly inhibited the proliferation and induced apoptosis of the HepG2 cells. The results of fluorescence micrographs showed that a 48-h treatment with gigantol induced typical apoptotic morphological features, which were consistent with the flow cytometric analysis where $20 \%$ of apoptotic cells were detected in response to gigantol treatment. In addition, western blot analysis indicated that gigantol enhanced the activities of caspase-3, PARP and p53 and downregulated the expression of p-Akt/Akt. Collectively, the present data suggest that gigantol induces growth inhibition and apoptosis of HepG2 cells via the PI3K/Akt/NF- $\mathrm{BB}$ signaling pathway.
\end{abstract}

\section{Introduction}

Hepatocellular carcinoma (HCC; liver cancer) is one of the most frequently occuring cancers in the world (1). The incidence rates (newly occurring cases per unit of population) and mortality rates in sub-Saharan Africa were 6.2 and $8.3 \%$, respectively (2). HCC is the third primary cause of cancer-related deaths worldwide, with an estimated 749,000 new cases annually, particularly in low income countries (3). Moreover, only a few HCC patients are indicated to receive

Correspondence to: Professor Gang Wei, School of Chinese Pharmaceutical Science, Guangzhou University of Chinese Medicine, Higher Education Mega Center, East Waihuan Road 232, Guangzhou 510006, P.R. China

E-mail: weigang021@163.com

*Contributed equally

Key words: gigantol, $\mathrm{PI} 3 \mathrm{~K} / \mathrm{Akt} / \mathrm{NF}-\kappa \mathrm{B}$ pathway, human liver cancer, apoptosis systemic chemotherapy treatment (4). However, HCC patients receiving chemotherapy with sorafenib, 5-fluorouracil and cisplatin may also present with severe side effects and multidrug drug resistance. Thus, therapy for HCC patients is still a severe challenge. Therefore, it is imperative to discover and develop natural anticarcinogens which are safe and effective. At present, natural products from medicinal plants such as, pure compounds such as sasanquasaponin (5) guggulsterone (6), xanthohumol (7) and isoliensinine polyphyllin VII (8) are used as alternative treatments due to their wide range of antiproliferative activities in human tumor cell lines.

Gigantol is a biphenyl phenolic compound primarily extracted from the stem of Dendrobium aurantiacum (9). Previous studies have confirmed that the phenolic compound extracted from Crataegus monogyna (10) inhibited the cell growth of human tumor cells including breast adenocarcinoma MCF-7, non-small cell lung cancer NCI-H460, cervical carcinoma HeLa and HCC HepG2 cell lines. Furthermore, it has been reported that gigantol possesses a variety of bioactivities including anti-osmotic (11), antitumor in lung cancer (12), antimutagenic (13) and immunomodulatory (14). In addition, gigantol has been described as a potent compound used in the recovery of sight in diabetic cataract disease (15). However, there have been no studies on the effects of gigantol on growth inhibition and apoptosis in human liver cancer.

One of the most significant intracellular signal transduction pathways is the phosphoinositol-3-kinase (PI3K/Akt) signaling pathway (16). When activated, the pathway regulates important cellular functions, including the promotion of cancer cell proliferation and inhibition of apoptosis by influencing the activity of downstream effector molecules (17). Moreover, it has been reported that when tumor cells are treated with wortmannin or LY294002, PI3K/Akt inhibitors (18), Akt phosphorylation not only leads to phosphorylation of blocked BAD, but also phosphorylates Ser 196 of caspase-9 and Ser 184 of Bax, which leads to the inactivation and inhibition of pro-apoptotic effects (19). NF- $\kappa \mathrm{B}$ is a common dimeric transcription factor (20) that plays a key role in the regulation of the expression of a variety of critical genes that regulate cell survival, proliferation, apoptosis, immune responses and changes in the intracellular redox balance (21). Several apoptosis-associated genes or regulatory proteins, such as p53, $\mathrm{Bax}, \mathrm{Bcl}-2$ and caspase-3, are reportedly activated or regulated by $\mathrm{NF}-\kappa \mathrm{B}$ in various tumor cells (22). 
In the present study, the anticancer effects of gigantolinduced growth inhibition and apoptosis of human liver cancer via the $\mathrm{PI} 3 \mathrm{~K} / \mathrm{Akt} / \mathrm{NF}-\mathrm{kB}$ signaling pathway were elucidated.

\section{Materials and methods}

Chemicals and materials. The human liver cancer HepG2 cell line was obtained from Guangzhou Jini Ou Biological Technology Co., Ltd. (Guangzhou, China). High glucose Dulbecco's modified Eagle's medium (H-DMEM), fetal bovine serum (FBS), penicillin-streptomycin, trypsin, trypsin (non-EDTA) and phosphate-buffered saline (PBS) were acquired from Gibco Chemical Co. (Rockville, MD, USA). 3-(4,5-Dimethyl-2-thiazolyl)-2,5-diphenyl-2-H-tetrazolium bromide (MTT) and dimethyl sulfoxide (DMSO) were acquired from Sigma-Aldrich (St. Louis, MO, USA). Gigantol was purchased from Chinese Materials Research Center (Daxing, Beijing, China). The chemical structure of gigantol is shown in Fig. 1. The Annexin V-FITC apoptosis assay and Hoechst 33258 assay kits were provided by KeyGen Biotech Co., Ltd. (Jiangsu, China). The PI3K/AKT inhibitor LY294002 was purchased from Selleck Chemicals (Houston, TX, USA). All other chemicals used were of analytical grade.

Cell culture. HepG2 cells were cultured in DMEM supplemented with $10 \%$ (v/v) FBS and $1 \%$ penicillin-streptomycin and incubated at $37^{\circ} \mathrm{C}$ in a humidified atmosphere containing $5 \% \mathrm{CO}_{2}$. The control group included HepG2 cells in the absence of gigantol in serum-free medium. To study the effects from the intervention of the inhibitor, the cells were pretreated with PI3K/AKT inhibitor LY294002 $(25 \mu \mathrm{mol} / \mathrm{l})$ for $1 \mathrm{~h}$, followed by treatment with gigantol.

Cell viability assay. The cytotoxicity was measured using MTT assays. Briefly, HepG2 cells were seeded in a 96-well plate $\left(5 \times 10^{4}\right.$ cells/well) and serum-starved for $24 \mathrm{~h}$ using H-DMEM (without FBS). Then the culture medium was replaced with H-DMEM containing a series of concentrations of gigantol $(1,10,40,80$ and $150 \mu \mathrm{M})$ for different time intervals $(12,24$ and $48 \mathrm{~h})$. After treatment, $20 \mu \mathrm{l}$ of MTT $(5 \mathrm{mg} / \mathrm{ml})$ was added to each well and continuously cultured for an additional $4 \mathrm{~h}$ at $37^{\circ} \mathrm{C}$. The cell supernatant was removed by aspiration and the formazan was dissolved with $150 \mu \mathrm{l}$ DMSO. The absorbance was read at $490 \mathrm{~nm}$ using a microplate reader (Bio-Rad Laboratories, Inc., Hercules, CA, USA). The cell viability was calculated as follows: cell viability $=\left(\mathrm{A}_{490}\right.$ experimental $/ \mathrm{A}_{490}$ control $) \times 100 \%$.

Morphological changes. The effect of gigantol on the morphological changes of HepG2 cells was assessed using the chromatin dye Hoechst 33258 . The HepG2 cells were cultured in 24-well plates $\left(5 \times 10^{4}\right.$ cells/well) overnight and then exposed to gigantol with concentrations of $0,1,40$ and $150 \mu \mathrm{M}$ for $48 \mathrm{~h}$. Subsequently, the cells were fixed with $4 \%$ paraformaldehyde for $10 \mathrm{~min}$ at $4^{\circ} \mathrm{C}$ and then dyed with Hoechst 33258 for $5 \mathrm{~min}$ in the dark after being washed by PBS twice. Morphological changes were observed by phase-contrast microscopy and the images of the apoptotic cells were visualized using a fluorescence microscope (Leica, Microsystems GmbH, Wetzlar, Germany).

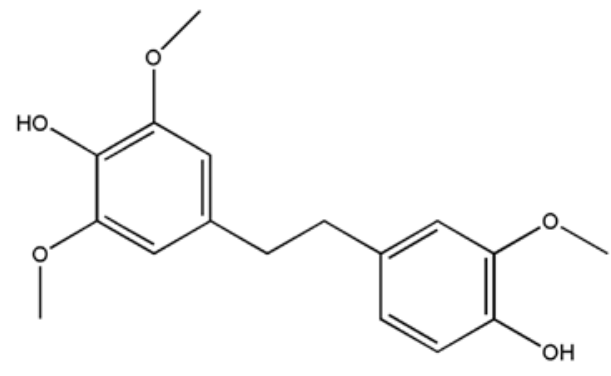

Figure 1. Chemical structure of gigantol.

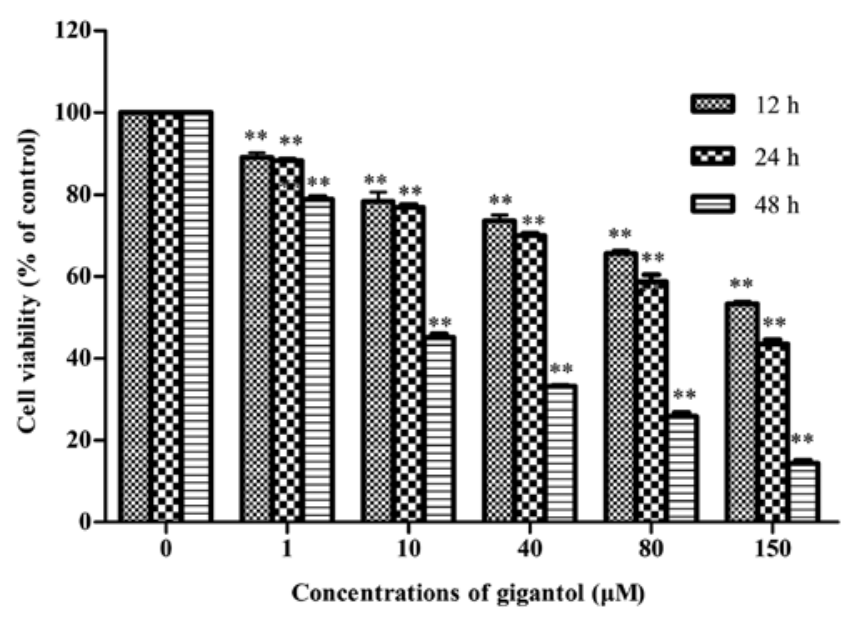

Figure 2. Effect of gigantol on the inhibition of HepG2 cell growth Determination of the effect of gigantol on the cytotoxicity in HepG2 cells using MTT assay. The cell viability was decreased dose- and time-dependently following incubatation with $1,10,40,80$ and $150 \mu \mathrm{M}$ gigantol for 12,24 and $48 \mathrm{~h} .{ }^{* *} \mathrm{P}<0.01$ compared to the $0 \mu \mathrm{M}$ gigantol group.

Flow cytometric analysis of cell apoptosis. HepG2 cells were seeded in 6 -well plates $\left(5 \times 10^{5}\right.$ cells/well). After the cells had attached to the culture plate, gigantol was added at concentrations of $0,1,40$ and $150 \mu \mathrm{M}$ for $48 \mathrm{~h}$. According to the manufacturer's instructions, HepG2 cells which were digested with trypsin (non-EDTA) were washed with PBS and harvested and then suspended in $500 \mu 1$ binding buffer. Following staining with $5 \mu \mathrm{l}$ Annexin V-FITC and $5 \mu \mathrm{l}$ propidium iodide (PI) for $10 \mathrm{~min}$ at room temperature in the dark, the samples were immediately analyzed using BD FACSCanto II flow cytometer.

Protein extraction and western blot analysis. HepG2 cells were seeded in 6 -well plates $\left(1 \times 10^{6}\right.$ cells/well) overnight. After treatment with or without gigantol or in combination with the inhibitor LY294002, the cells were collected, washed with cold PBS, and resuspended in cold RIPA buffer with a protein inhibitor. Then the cellular protein was collected and the protein concentration was determined using the Bradford assay. Equal amounts of protein (40 $\mu \mathrm{g} / \mathrm{lane})$ were separated on 15\% SDS-polyacrylamide gels and transferred onto polyvinylidene difluoride membranes via electrophoresis. After blocking with Tris-buffered saline (TBS) containing 5\% skimmed milk and $0.05 \%$ Tween- 20 for $1 \mathrm{~h}$, the membranes were incubated with primary antibodies Akt, p-Akt, PARP, 

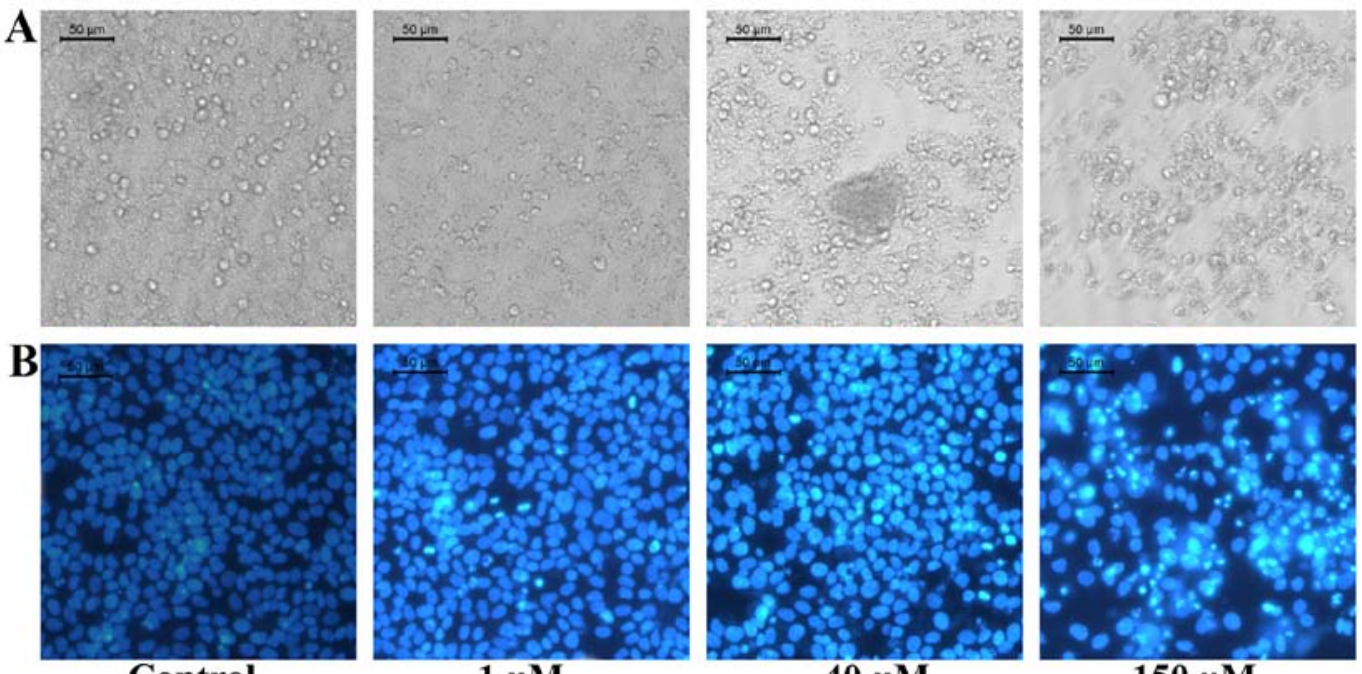

$40 \mu \mathrm{M}$

$150 \mu \mathrm{M}$

Figure 3. (A) Effect of gigantol on the morphological changes in HepG2 cells using an inverted microscope. (B) Effect of gigantol on the morphological changes in HepG2 cells using fluorescence microscopy. Nuclear staining with Hoechst 33258 using fluorescence microscopy showed that gigantol induces typical apoptosis including blebbing, cytoplasm condensation and nuclear fragmentation with condensed chromatin.

p53 and $\beta$-actin at $4^{\circ} \mathrm{C}$ overnight. Following three washes with TBS for $5 \mathrm{~min}$, the membranes were incubated with horseradish peroxidase-conjugated with goat anti-rabbit immunoglobulin $\mathrm{G}$ for $1 \mathrm{~h}$ at room temperature. Finally, the protein bands were washed with TBST three times and visualized using an ECL western blot analysis kit according to the manufacturer's instructions.

Statistical analysis. Data shown in this study are presented as the mean \pm SEM and the results from each group were obtained using triplicate samples independently. A one-way ANOVA was used to determine the differences among the groups. A probability value of ${ }^{*} \mathrm{P}<0.05$ was considered to be statistically significant, while ${ }^{* *} \mathrm{P}<0.01$ was considered to be highly statistically significant and are indicated in the figures. All statistical analyses were carried out using Prism5 software package (GraphPad Software Inc., La Jolla, CA, USA).

\section{Results}

Anticancer effect of gigantol on the inhibition of HepG2 cell growth. The effect of gigantol on the viability of the HepG2 cells was measured by MTT assay. As indicated in Fig. 2, gigantol inhibited the growth of HepG2 cells in a dose- and time-dependent manner, particularly at a concentration beyond $10 \mu \mathrm{M}$ at $48 \mathrm{~h}$. Gigantol at concentrations of 1,40 and $150 \mu \mathrm{M}$ markedly decreased the cell viability by $11.7,30.0$ and $56.4 \%$ at $24 \mathrm{~h}$ and $21.1,66.8$ and $85.5 \%$ at $48 \mathrm{~h}$, respectively. The $\mathrm{IC}_{50}(48 \mathrm{~h})$ value was $9.30 \mu \mathrm{M}$. Thus, the concentrations of 1,40 and $150 \mu \mathrm{M}$ and the incubation period of $48 \mathrm{~h}$ were the optimal parameters to carry out further experiments.

Anticancer effect of gigantol on the morphological changes of HepG2 cells. The morphological changes and apoptotic morphology of HepG2 cells were investigated by fluorescence microscopy, as shown in Fig. 3. Following treatment with gigantol $(1,40$ and $150 \mu \mathrm{M})$ for $48 \mathrm{~h}$, the cells exhibited membrane blebbing, cytoplasm condensation, and nuclear fragmentation with condensed chromatin typical characteristics of apoptosis. This suggests that gigantol inhibits the growth of HepG2 cells by inducing the apoptotis of tumor cells.

Anticancer effect of gigantol on the apoptosis rate of HepG2 cells. We evaluated cell apoptosis using the Annexin V and PI double-staining assay using flow cytometry. As depicted in Fig. 4, after incubation with gigantol (1, 40 and $150 \mu \mathrm{M})$ for $48 \mathrm{~h}$, the apoptosis rates were $9.9,14.9$ and $20.7 \%$, respectively. All of the values were higher than that in the control group, which demonstrated a significant increase in the cell apoptosis rate.

Anticancer effect of gigantol involves inhibition of $p$-Akt/Akt in human liver cancer cells. As previously reported, the PI3K/ Akt pathway plays an important role in cell survival under stimulation (23). Therefore, to investigate whether gigantol inhibits the phosphorylation of Akt, HepG2 cells were treated with gigantol at concentrations of 1,40 and $150 \mu \mathrm{M}$ for $48 \mathrm{~h}$ (Fig. 5). Western blot analysis showed that the p-Akt protein expression level was decreased in a dose-dependent manner. In addition, there was a significant decrease in the ratio of p-Akt/ Akt following treatment with gigantol, which was further suppressed by LY294002.

Anticancer effect of gigantol involves the induction of PARP signaling in human liver cancer cells. Western blot analysis was performed to detect PARP protein expression in HepG2 cells which were treated with gigantol. As shown in Fig. 6, significant upregulation of PARP protein expression was observed in the HepG2 cells treated with gigantol $(1,40$ and $150 \mu \mathrm{M})$ and LY294002 further increased the expression of PARP.

Anticancer effect of gigantol involves the induction of p53 signaling in human liver cancer cells. We investigated whether the anticancer effect of gigantol involves p53 signaling in 
A
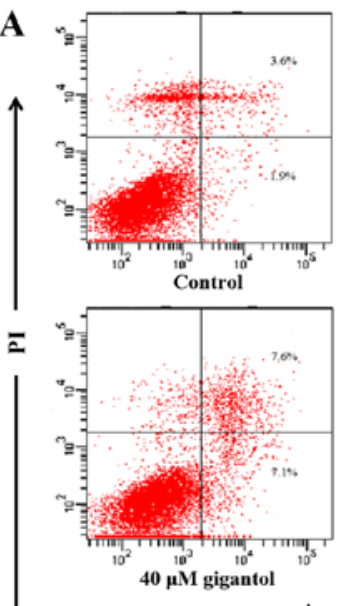
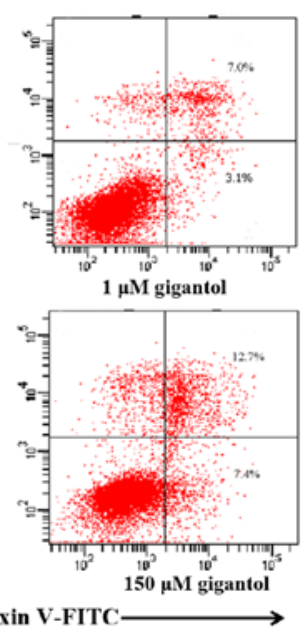

B

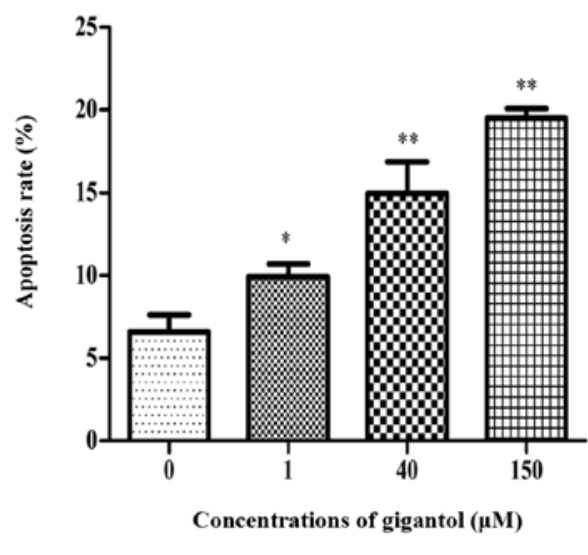

Figure 4. (A) Effect of gigantol on cell apoptosis in HepG2 cells. (B) HepG2 cells were treated with $0,1,40$ and $150 \mu \mathrm{M}$ of gigantol for $48 \mathrm{~h}$ and the percentage of apoptotic cells was determined using Annexin V-FITC and PI. ${ }^{*} \mathrm{P}<0.05$ and ${ }^{* *} \mathrm{P}<0.01$ compared with the $0 \mu \mathrm{M}$ gigantol group.

A

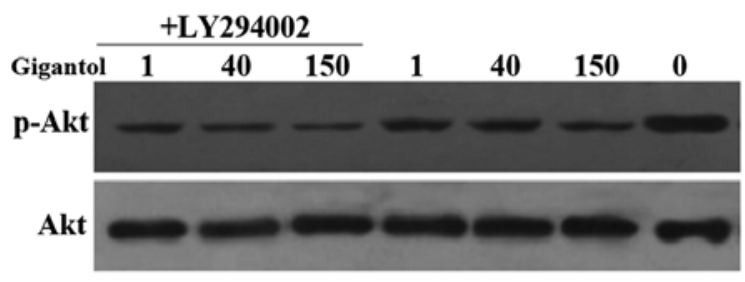

B

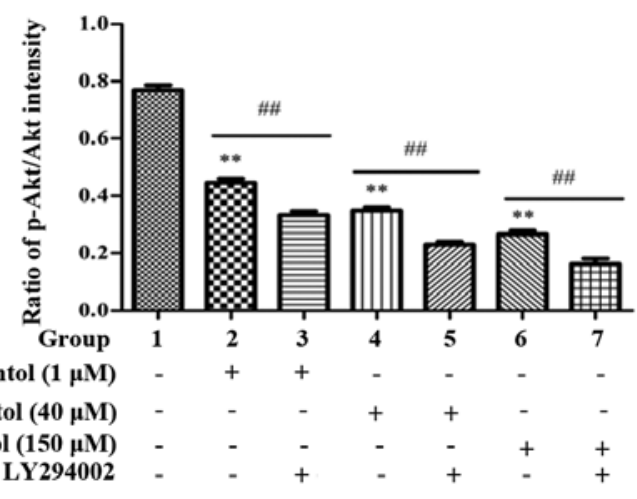

Figure 5. Anticancer effect of gigantol involves inhibition of pAkt/Akt in human liver cancer cells. (A) Western blot analysis. (B) The ratio of pAkt/Akt expression was decreased as detected using western blot analysis in gigantol-treated cells. Gigantol attenuated the ratio of pAkt/Akt dose-dependently, which was further suppressed by LY294002. Akt was used as a loading control. ${ }^{* *} \mathrm{P}<0.01$ compared to the $0 \mu \mathrm{M}$ gigantol group. ${ }^{\# \# ~} \mathrm{P}<0.01$, gigantol pretreatment compared to gigantol pretreatment with LY294002.

A

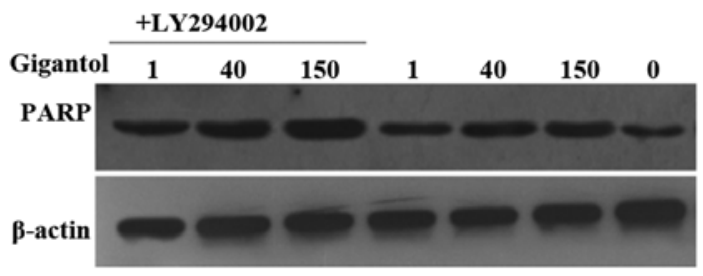

B

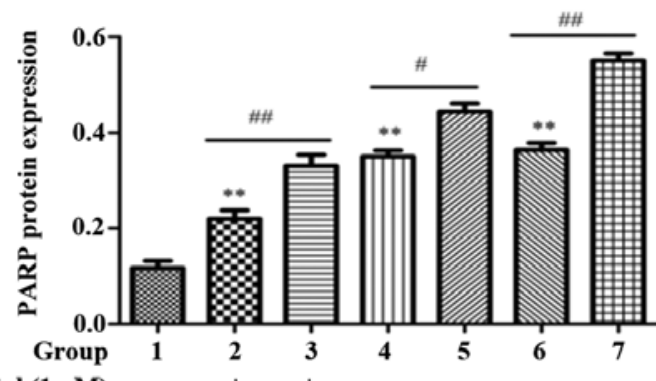

Gigantol $(1 \mu \mathrm{M})$

Gigantol $(40 \mu \mathrm{M})$

Gigantol $(150 \mu \mathrm{M})$

Figure 6. Anticancer effect of gigantol involves the induction of PARP in human liver cancer cells. (A) Western blot analysis. (B) Anticancer effect of gigantol involves the induction of PARP signaling in human liver cancer cells. Expression of PARP was increased as detected using western blot analysis in gigantoltreated cells. Gigantol considerably promoted the upregulation of PARP and LY294002 further increased the expression of PARP. $\beta$-actin was used as a loading control. ${ }^{* *} \mathrm{P}<0.01$ compared to the $0 \mu \mathrm{M}$ gigantol group. ${ }^{\#} \mathrm{P}<0.05$ and ${ }^{\# \#} \mathrm{P}<0.01$, gigantol pretreatment compared to gigantol pretreatment with $\mathrm{LY} 294002$.

human liver cancer cells by western blot analysis. As shown in Fig. 7, following gigantol treatment, p53 protein expression was increased in the HepG2 cells and LY294002 further increased the expression of p53.
Anticancer effect of gigantol involves the induction of caspase-3 signaling in human liver cancer cells. To determine whether gigantol induces the apoptosis of HepG 2 cells, caspase-3 activity was assessed. Fig. 8 demonstrates that 
A

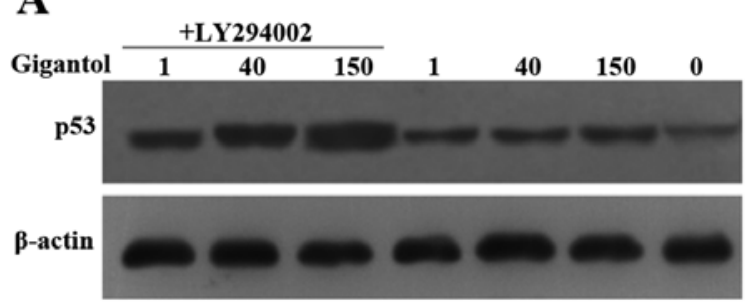

B

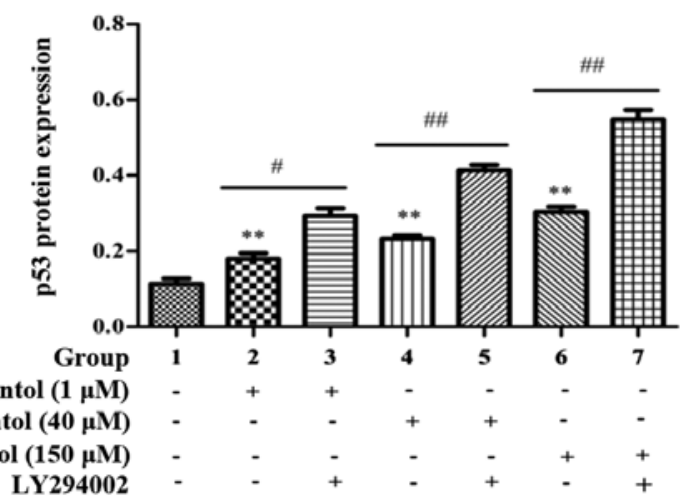

Figure 7. Anticancer effect of gigantol involves the induction of p53 in human liver cancer cells. (A) Western blot analysis. (B) Anticancer effect of gigantol involves the induction of p53 signaling in human liver cancer cells. Expression of p53 was increased as detected using western blot analysis in the gigantoltreated cells. Gigantol significantly promoted the upregulation of PARP and the effect was synergized with the application of LY294002. $\beta$-actin was used as a loading control. ${ }^{* *} \mathrm{P}<0.01$ compared to the $0 \mu \mathrm{M}$ gigantol group. ${ }^{\#} \mathrm{P}<0.05$ and ${ }^{\# \#} \mathrm{P}<0.01$, gigantol pretreatment compared to gigantol pretreatment with LY294002.
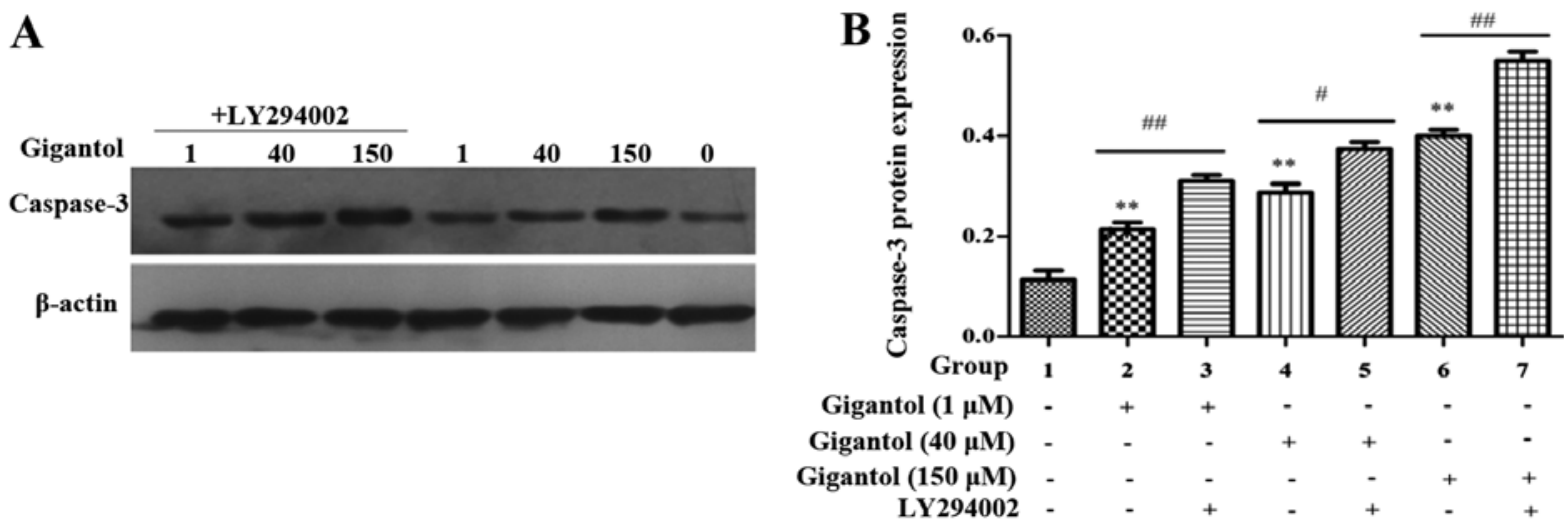

Figure 8. Anticancer effect of gigantol involves the induction of caspase-3 in human liver cancer cells. (A) Western blot analysis. (B) Anticancer effect of gigantol involves the induction of caspase-3 signaling in human liver cancer cells. Expression of caspase-3 was increased as detected using western blot analysis in the gigantol-treated cells. Gigantol markedly promoted the upregulation of caspase-3 and was further increased by the application of LY294002. $\beta$-actin was used as a loading control. ${ }^{* *} \mathrm{P}<0.01$ compared to the $0 \mu \mathrm{M}$ gigantol group. ${ }^{\#} \mathrm{P}<0.05$ and ${ }^{\# \#} \mathrm{P}<0.01$, gigantol pretreatment compared to gigantol pretreatment with LY294002.

gigantol significantly increased caspase- 3 activity in the HepG2 cells.

\section{Discussion}

Apoptosis, which is a process of cell suicide, is associated with characteristic morphological changes, such as condensation of chromatin, blebbing formation and biochemical changes (24). In apoptotic cells, the membrane phospholipid phosphatidylserine (PS) is translocated from the inner to the outer leaflet of the plasma membrane, thereby exposing PS to the external cellular environment. Annexin V has a high affinity for PS, and binds to cells with exposed PS. Annexin V is conjugated to FITC and serves as a sensitive probe for flow cytometric analysis. Thus, since externalization of PS occurs in the earlier stages of apoptosis, FITC Annexin V staining can identify apoptosis at earlier stages $(25,26)$. The present study revealed that HepG2 cells were increased in a dose-dependent manner when exposed to PS, which was manifested when gigantol-induced cells entered the early stages of apoptosis.

Previous studies have shown that the PI3K/Akt pathway is crucial to many aspects of cell growth, survival and apoptosis and implicated in inducing cell metabolism, proliferation, migration and survival (27), while NF- $\mathrm{B}$ is usually associated with suppression of cell proliferation, invasion, tumor metastasis and apoptosis (28). Simultaneous activation with multiple signaling pathways may lead to undesirable therapy, therefore, the PI3K/Akt/NF- $\kappa \mathrm{B}$ signaling pathway is important in the stimulation of tumor cell survival, chemosensitivity, and invasive behavior in a variety of cancer signaling pathways (29). In a previous study, Shan et al (30) indicated that the inhibition of Aurora-B suppressed HepG2 cells by decreasing the protein expression levels of $\mathrm{p}-\mathrm{Akt}, \mathrm{Akt}, \mathrm{NF}-\kappa \mathrm{B}$ p65, MMP-2 and MMP-9 via the modulation of the PI3K/Akt/NF- $\kappa B$ signaling pathway in vitro.

PARP plays a significant role in genomic stability and in the process of apoptosis in the modulation of DNA replication and transcription (31). When DNA is broken and damaged, activated PARP participates in combining with DNA breakage, which may protect the terminal of bare DNA from the catabolic reaction by nuclease (32). Also, in response to DNA damage, p53, one of the most significant members of the tumor-suppressor proteins, markedly promotes the genes responsible for cell proliferation and migration (33). Zhao et al (7) reported that 
xanthohumol induced growth inhibition and apoptosis through an increase in cleaved PARP and p53 in human liver cancer.

In summary, the present study revealed for the first time, that gigantol, a monomer compound isolated from Dendrobium aurantiacum, exerted growth inhibition and apoptosis against human liver cancer cells through the PI3K/ $\mathrm{Akt} / \mathrm{NF}-\mathrm{kB}$ signaling pathway and the anticancer effects of gigantol induced growth inhibition and apoptosis through an increase in cleaved PARP, p53, caspase-3 and a decreased ratio of p-Akt/Akt in human liver cancer cells. Our findings provide confirmation of the anticancer effect of gigantol in human liver cancer. However, it is still necessary to investigate further in order to elucidate its pro-apoptotic effects and the underlying biochemical mechanisms involved.

\section{Acknowledgements}

The authors are grateful for the financial support by the Special Foundation of 2015 High Level University Construction (no. 2050205).

\section{References}

1. Yu F, Shen X, Fan L and Yu Z: Analysis of histone modifications at human ribosomal DNA in liver cancer cell. Sci Rep 5: $18100,2015$.

2. Bosch FX, Ribes J, Díaz M and Cléries R: Primary liver cancer: Worldwide incidence and trends. Gastroenterology 127 (Suppl 1): S5-S16, 2004.

3. Palliyaguru DL and Wu F: Global geographical overlap of aflatoxin and hepatitis $\mathrm{C}$ : Controlling risk factors for liver cancer worldwide. Food Addit Contam Part A Chem Anal Control Expo Risk Assess 30: 534-540, 2013.

4. Lin L, Fang Z, Lin H, You H, Wang J, Su Y, Wang F and Zhang ZY: Depletion of Cks1 and Cks2 expression compromises cell proliferation and enhance chemotherapy-induced apoptosis in HepG2 cells. Oncol Rep 35: 26-32, 2016

5. Zeng J, Chen S, Li N, Chen L, Su J, Niu G, Zhu S and Liang Y: Sasanquasaponin from Camellia oleifera Abel. induces apoptosis via Bcl-2, Bax and caspase-3 activation in HepG2 cells. Mol Med Rep 12: 1997-2002, 2015

6. Shi JJ, Jia XL, Li M, Yang N, Li YP, Zhang X, Gao N and Dang SS: Guggulsterone induces apoptosis of human hepatocellular carcinoma cells through intrinsic mitochondrial pathway. World J Gastroenterol 21: 13277-13287, 2015.

7. Zhao X, Jiang K, Liang B and Huang X: Anticancer effect of xanthohumol induces growth inhibition and apoptosis of human liver cancer through $\mathrm{NF}-\kappa \mathrm{B} / \mathrm{p} 53$-apoptosis signaling pathway. Oncol Rep 35: 669-675, 2016.

8. Shu G, Yue L, Zhao W, Xu C, Yang J, Wang S and Yang X: Isoliensinine, a bioactive alkaloid derived from embryos of Nelumbo nucifera, induces hepatocellular carcinoma cell apoptosis through suppression of NF- $\kappa \mathrm{B}$ signaling. J Agric Food Chem 63: 8793-8803, 2015.

9. Yang L, Wang $\mathrm{Z}$ and $\mathrm{Xu} \mathrm{L}$ : Phenols and a triterpene from Dendrobium aurantiacum var. denneanum (Orchidaceae). Biochem Syst Ecol 34: 658-660, 2006.

10. Rodrigues S, Calhelha RC, Barreira JCM, Dueñas $M$, Carvalho AM, Abreu RMV, Buelga CS and Ferreira ICFR: Crataegus monogyna buds and fruits phenolic extracts: Growth inhibitory activity on human tumor cell lines and chemical characterization by HPLC-DAD-ESI/MS. Food Res Int 49: 516-523, 2012.

11. Fang H, Hu X, Wang M, Wan W, Yang Q, Sun X, Gu Q, Gao X, Wang Z, Gu L, et al: Anti-osmotic and antioxidant activities of gigantol from Dendrobium aurantiacum var. denneanum against cataractogenesis in galactosemic rats. J Ethnopharmacol 172: 238-246, 2015.

12. Bhummaphan $\mathrm{N}$ and Chanvorachote P: Gigantol suppresses cancer stem cell-like phenotypes in lung cancer cells. Evid-Based Compl Al 2015: 1-10, 2015.
13. Miyazawa $M$, Shimamura $H$, Nakamura $S$ and Kameoka $H$ : Antimutagenic activity of gigantol from Dendrobium nobile. J Agric Food Chem 45: 2849-2853, 1997.

14. Won JH, Kim JY, Yun KJ, Lee JH, Back NI, Chung HG, Chung SA, Jeong TS, Choi MS and Lee KT: Gigantol isolated from the whole plants of Cymbidium goeringii inhibits the LPS-induced iNOS and COX-2 expression via NF- $\kappa$ B inactivation in RAW 264.7 macrophages cells. Planta Med 72: 1181-1187, 2006.

15. Wu J, Lu C, Li X, Fang H, Wan W, Yang Q, Sun X, Wang M, Hu X, Chen CY, et al: Synthesis and biological evaluation of novel gigantol derivatives as potential agents in prevention of diabetic cataract. PLoS One 10: e0141092, 2015.

16. Song G, Ouyang G and Bao S: The activation of Akt/PKB signaling pathway and cell survival. J Cell Mol Med 9: 59-71, 2005.

17. Rychahou PG, Jackson LN, Silva SR, Rajaraman S and Evers BM: Targeted molecular therapy of the PI3K pathway: Therapeutic significance of PI3K subunit targeting in colorectal carcinoma. Ann Surg 243: 833-842, 2006.

18. Fresno Vara JA, Casado E, de Castro J, Cejas P, Belda-Iniesta C and González-Barón M: PI3K/Akt signalling pathway and cancer. Cancer Treat Rev 30: 193-204, 2004.

19. Xin M and Deng X: Nicotine inactivation of the proapoptotic function of Bax through phosphorylation. J Biol Chem 280: 10781-10789, 2005.

20. Dey A, Tergaonkar V and Lane DP: Double-edged swords as cancer therapeutics: Simultaneously targeting p53 and NF- $\mathrm{KB}$ pathways. Nat Rev Drug Discov 7: 1031-1040, 2008.

21. Chariot A: The NF- $\kappa B$-independent functions of IKK subunits in immunity and cancer. Trends Cell Biol 19: 404-413, 2009.

22. Kim SM, Lee SY, Yuk DY, Moon DC, Choi SS, Kim Y, Han SB Oh KW and Hong JT: Inhibition of NF- $\kappa$ B by ginsenoside Rg3 enhances the susceptibility of colon cancer cells to docetaxel. Arch Pharm Res 32: 755-765, 2009.

23. Maddika S, Ande SR, Panigrahi S, Paranjothy T, Weglarczyk K, Zuse A, Eshraghi M, Manda KD, Wiechec E and Los M: Cell survival, cell death and cell cycle pathways are interconnected: Implications for cancer therapy. Drug Resist Updat 10: 13-29, 2007.

24. Hu Q, Pan R, Wang L, Peng B, Tang J and Liu X: Platycodon grandiflorum induces apoptosis in SKOV3 human ovarian cancer cells through mitochondrial-dependent pathway. Am J Chin Med 38: 373-386, 2010.

25. van Engeland M, Nieland LJ, Ramaekers FC, Schutte B and Reutelingsperger CP: Annexin V-affinity assay: A review on an apoptosis detection system based on phosphatidylserine exposure. Cytometry 31: 1-9, 1998.

26. Andree HA, Reutelingsperger CP, Hauptmann R, Hemker HC, Hermens WT and Willems GM: Binding of vascular anticoagulant $\alpha$ (VAC $\alpha$ ) to planar phospholipids bilayers. Blood Coagul Fibrinolysis 5: 921-928, 1994.

27. Stambolic V and Woodgett JR: Functional distinctions of protein kinase $\mathrm{B} / \mathrm{Akt}$ isoforms defined by their influence on cell migration. Trends Cell Biol 16: 461-466, 2006.

28. Kim HJ, Kim JC, Min JS, Kim MJ, Kim JA, Kor MH, Yoo HS and Ahn JK: Aqueous extract of Tribulus terrestris Linn induces cell growth arrest and apoptosis by down-regulating NF- $\kappa B$ signaling in liver cancer cells. J Ethnopharmacol 136: 197-203, 2011.

29. Azijli K, Weyhenmeyer B, Peters GJ, de Jong S and Kruyt FA: Non-canonical kinase signaling by the death ligand TRAIL in cancer cells: Discord in the death receptor family. Cell Death Differ 20: 858-868, 2013.

30. Shan RF, Zhou YF, Peng AF and Jie ZG: Inhibition of Aurora-B suppresses HepG2 cell invasion and migration via the $\mathrm{PI} 3 \mathrm{~K} / \mathrm{Akt} / \mathrm{NF}-\kappa \mathrm{B}$ signaling pathway in vitro. Exp Ther Med 8: 1005-1009, 2014.

31. Booth L, Cruickshanks N, Ridder T, Dai Y, Grant S and Dent P: PARP and CHK inhibitors interact to cause DNA damage and cell death in mammary carcinoma cells. Cancer Biol Ther 14: 458-465, 2013.

32. Kulkarni A, Oza J, Yao M, Sohail H, Ginjala V, Tomas-Loba A, Horejsi Z, Tan AR, Boulton SJ and Ganesan S: Tripartite motif-containing 33 (TRIM33) protein functions in the poly(ADP-ribose) polymerase (PARP)-dependent DNA damage response through interaction with Amplified in Liver Cancer 1 (ALC1) protein. J Biol Chem 288: 32357-32369, 2013.

33. Brown CJ, Lain S, Verma CS, Fersht AR and Lane DP: Awakening guardian angels: Drugging the p53 pathway. Nat Rev Cancer 9: 862-873, 2009. 